\title{
Women Empowerment: Perspectives and Views
}

\author{
Dr Tanu Tandon ${ }^{1 *}$
}

Keywords: Women, Empowerment

“Empowerment” has been used to represent a wide range of concepts and to describe a proliferation of outcomes. The term has been used more often to advocate for certain types of policies and intervention strategies than to analyze them, as demonstrated by a number of documents from the United Nations (UNDAW 2001; UNICEF 1999), the Association for Women in Development (Everett 1991), the Declaration made at the Micro-credit Summit (RESULTS 1997), DFID (2000), and other organizations. Empowerment has become a widely used word.

Empowerment in its emancipatory meaning is a serious word one which brings up the question of personal agency, one that links action to needs, and one that results in making significant collective change. It is also a concept that does not merely concern personal identity but brings out a broader analysis of human rights and social justice. Applied to gender issues, the discussion of empowerment brings women into the political sphere, both private and public. In this context, empowerment is a process to change the distribution of power between men and women, both in interpersonal relations and in institutions throughout society. The concept of women's empowerment emerged from several important critiques and debates generated by the women's movement throughout the world during the 1980s, when feminists, particularly in the Third World, were increasingly discontent with the largely apolitical and economist 'WID', 'WAD', and 'GAD' models in prevailing development interventions .

There was growing interaction between feminism and the concept and practice of popular education, based on the 'conscientisation' approach developed by Paulo Freire in Latin America in the 1970s as part of his 'liberation theology'. The interplay of these powerful new discourses led, by the mid-1980s, to the spread of 'women's empowerment' as a more political and transformatory idea for struggles that challenged not only patriarchy, but also the mediating structures of class, race, ethnicity - and, in India, caste and religion - which determined the nature of women's position and condition in developing societies. The sharp political perspective

\footnotetext{
${ }^{1}$ Asst Professor, Amity Institute of Education, Amity University, Lucknow Campus

*Responding Author

(C) 2016 I T Tandon; licensee IJIP. This is an Open Access Research distributed under the terms of the Creative Commons Attribution License (http://creativecommons.org/licenses/by/2.0), which permits unrestricted use, distribution, and reproduction in any Medium, provided the original work is properly cited.
} 
from which it arose became diffused and diluted. Development-assistance agencies (multilateral, bilateral, and private), eternally in search of catchphrases and magic bullets that could somehow trigger the process of social transformation, took hold of the term and began to use it to replace their earlier terminology of 'people's participation' and 'women's development'.The1995FourthWorld Conference on Women in Beijing played a critical role in introducing the 'e' word to state actors, and governments anxious to demonstrate a progressive approach to gender quickly adopted the catchphrase of women's empowerment. The most important point, however, is that all efforts to conceptualise the term more clearly stressed that empowerment was a socio-political process, that the critical operating concept within empowerment was power, and that empowerment was about shifts in political, social, and economic power between and across both individuals and social groups.

\section{Conceptualizing women's empowerment}

Given the diversity in the emphases and agendas in discussions on women's empowerment, we found greater consensus in the literature on its conceptualization. There is a nexus of a few key, overlapping terms that are most often included in defining empowerment: options, choice, control, and power. Most often these are referring to women's ability to make decisions and affect outcomes of importance to themselves and their families. Control over one's own life and over resources is often stressed. Thus, there is frequent reference to some variant of the ability to "affect one’s own well being," and "make strategic life choices." G. Sen (1993) defines empowerment as "altering relations of power...which constrain women's options and autonomy and adversely affect health and well-being." Batliwala's (1994) definition is in terms of "how much influence people have over external actions that matter to their welfare." Keller and Mbwewe (1991, as cited in Rowlands 1995) describe it as "a process whereby women become able to organize themselves to increase their own self-reliance, to assert their independent right to make choices and to control resources which will assist in challenging and eliminating their own subordination". Also appearing frequently in definitions of empowerment is an element related to the concept of human agency -- self-efficacy. Drawing mainly from the human rights and feminist perspectives, many definitions contain the idea that a fundamental shift in perceptions, or "inner transformation," is essential to the formulation of choices. That is, women should be able to define self interest and choice, and consider themselves as not only able, but entitled to make choices (A. Sen 1999; G. Sen 1993, Kabeer 2001; Rowlands 1995, Chen 1992). Kabeer (2001) goes a step further and describes this process in terms of "thinking outside the system" and challenging the status quo. Kabeer (2001) offers a useful definition of empowerment that effectively captures what is common to these definitions and that can be applied across the range of contexts that development assistance is concerned with: "The expansion in people's ability to make strategic life choices in a context where this ability was previously denied to them."

Let's look at the perspectives given by Batliwala, Kabeer and Rowlands, three of the most often cited writers on women's empowerment. 


\section{Batliwala - challenging patriarchal relations}

Batliwala surveyed organisations working for women's empowerment in South Asia in the early 1990s to stimulate discussion and improve programming (1993: 4-5). She suggests that "the process of challenging existing power relations, and of gaining greater control over the sources of power, may be termed empowerment" (1994: 130). According to Batliwala, "the goals of women's empowerment are to challenge patriarchal ideology; to transform the structures and institutions that reinforce and perpetuate gender discrimination and social inequality;... and to enable poor women to gain access to, and control of, both material and informational resources" (1994: 130). She focuses on gender while recognising and trying to address multiple discriminations. Batliwala recommends a comprehensive and integrated approach whereby women address their own objectives in the domestic and public spheres, and take collective and mass action. She quotes Schuler and Kadirgamar-Rajasingham: "since the causes of women's inferior status and unequal gender relations are deeply rooted in history, religion, culture, in the psychology of the self, in laws and legal systems, and in political institutions and social attitudes, if the status and material conditions of women's lives is to change at all, the solutions must penetrate just as deeply"

(1992, in Batliwala 1994: 130). That is, comprehensive strategies are needed if feminist social change is to be realised, Batliwala's vision remains focused on the societal level. Batliwala stresses that women's empowerment is a political process, fraught with challenges.

She does stress that changes will not be "sustainable if limited to a few individual women, because traditional power structures will seek to isolate and ostracise them," and so advocates for women organising into collectives and ultimately into mass movements (1994: 132-4).

\section{Kabeer - Resources, agency and achievements}

Kabeer also sees women as the key agents for feminist social change. She writes that "the capacity of those who have a stake in challenging the status quo to deal with resistance cannot be taken for granted; it has to be built up through processes of empowerment" (1999b: 32). That is, women's empowerment is a process for developing agents of social change.

Kabeer defines empowerment as "the expansion in people's ability to make strategic life choices in a context where this ability was previously denied to them." Kabeer's 'strategic life choices' are major decisions "such as choice of livelihood, whether and who to marry," recognising that not all choices are equally significant (1999a: 437). She sees three dimensions to empowerment resources, agency and achievements - each of which builds on the others. Resources can be material, human or social, including physical resources, individual capabilities and claims that the individual can make on others. Kabeer writes that "the terms on which people gain access to resources are as important as the resources themselves when the issue of empowerment is being considered" and that "empowerment entails a change in the terms on which resources are acquired as much as an increase in access to resources" (2001: 20). For Kabeer, agency includes 
"the meaning, motivation and purpose which individuals bring to their activity, their sense of agency, or 'the power within'".

Kabeer recognises that the choices open to women are often limited compared to men of the same community - a manifestation of gender inequality - and that women can internalise their lesser status in society (2001: 24). The critical factor is whether the choices that people are making are based on their own preferences and priorities, or limitations in their options. To show a link between individual choice and wider social change, Kabeer suggests evaluating the consequences of choices "in terms of their transformatory significance, the extent to which the choices made have the potential for challenging and destabilising social inequalities and the extent to which they merely reproduce these inequalities" (2001: 26). Kabeer defines three levels at which empowerment - and presumably wider social change - may be achieved, the individual or immediate, the intermediate level of institutions and deeper levels in terms of structural relations of class, caste or gender (2001: 27).

\section{Rowlands - spheres of empowerment}

Rowlands does not clearly define empowerment, other than to say that "women's empowerment... encompasses women moving into positions of 'power over', but... also embraces their movement into 'power to, with and from within' - generative rather than controlling power" (1998: 15). That is, women's empowerment involves changing the nature of power relations to be less controlling and more productive, as well as increasing women's power in every form. Whereas Kabeer's definition of empowerment is limited to "those who have been denied the ability to make strategic life choices acquire such an ability," (1999: 435), Rowlands sees empowerment as relative to one's own prior abilities. She identifies empowerment of women in three spheres, the individual empowerment, collective or group empowerment, and empowerment in close relationships ( 1998). Each form of empowerment supports the others, but is distinct in nature. The first is key, "a personal and unique experience, even though one woman may go through some similar experiences" to others (Rowlands 1998: 22). Collective empowerment is both the result of and builds the capacity of a group of people to work together to achieve common goals; it also contributes to the individual empowerment of each member by building their confidence and sense of agency. 'Empowerment in close relationships' with husbands, parents and mothers-in-law, "is the area of change that comes hardest; it is the place where the individual women is 'up against it on her own', and where positive and negative aspects of her life tend to be most closely intertwined" (Rowlands 1998: 23).

Rowlands identifies each of the elements that are needed for each type of empowerment. For empowerment in close relationships, she identified the ability to negotiate, communicate, to get support, to defend self/rights as well as a sense of 'self' in the relationship and dignity (1998: 24). It appears that if women can return to their families with these skills, they should be able to experience empowerment in close relationships. However, she concludes that "the empowerment of women is... not just a women's issue, but is a gender issue which necessitates a re- 
examination of gender relations, and which, ultimately, will require changes of men as well as of women" (1998: 30).

\section{Key lessons from the literature}

The literature contains a range of terms, concepts and data that may be relevant for assessing "empowerment"; for example, various studies have aimed at measuring women's "autonomy" (e.g. Dyson and Moore 1983; Basu and Basu 1991), agency, status, , domestic economic power (e.g. Mason 1998), power (e.g. Agarwal 1997), patriarchy (e.g. Malhotra et al. 1995), gender equality, or gender discrimination. Often there is no clear demarcation between these terms. Mason and Smith (2000), for example, treat empowerment, autonomy, and gender stratification interchangeably. Similarly, Jejeebhoy (2000) considers autonomy and empowerment as more or less equal terms, and defines both in terms of women "gaining control of their own lives vis-avis family, community, society, markets.” In contrast, other authors have explicitly argued that autonomy is not equivalent to empowerment, stressing that autonomy implies independence whereas empowerment may well be achieved through interdependence (Malhotra and Mather 1997; Govindasamy and Malhotra 1996; Kabeer 1998). Notwithstanding the similarities in the concepts underlying many of these terms, we think that the concept of empowerment can be distinguished from others based on its unique definitional elements. As discussed above, the first essential element of empowerment is that it is a process (Kabeer 2001; Chen 1992; Rowlands 1995, Oxaal and Baden 1997). None of the other concepts explicitly encompasses a progression from one state (gender inequality) to another (gender equality). The second element of empowerment that distinguishes it from other concepts is agency-in other words, women themselves must be significant actors in the process of change that is being described or measured (G. Sen 1993; Mehra 1997). The importance of agency in the discourse on empowerment emerges from "bottom up" rather than "top down" approaches toward development (Oxaal and Baden 1997; Rowlands 1995; Narayan et al. 2000a \& 2000b). At the institutional and aggregate levels, it emphasizes the importance of participation and "social inclusion” (Friedmann 1992; Chambers 1997; Narayan et al. 2000a \& 2000b) At the micro level, it is embedded in the idea of self-efficacy and the significance of the realization by individual women that they can be the agents of change in their own lives.

\section{Empowerment: Cognitive, Psychological and Economic Components}

According to Stromquist (1988), empowerment is a socio-political concept that goes beyond 'participation', and 'consciousness-raising'. She calls for a fuller definition of empowerment that considers cognitive, psychological and economic components.

- The cognitive component refers to women's understanding of their conditions of subordination and the causes of such conditions at both micro and macro levels of society. It involves understanding the self and the need to make choices that may go against cultural and social expectations, and understanding patterns of behaviour that create dependence, interdependence, and autonomy within the family and in the society at large (Hall, 1992). The 
cognitive component of empowerment involves knowledge about their sexuality beyond family planning techniques, another important cognitive area involves legal rights.

- The psychological component includes the development of feelings that women can act at personal and societal levels to improve their condition as well as the formation of the belief that they can succeed in their change efforts. The sex role socialization of women The political component has inculcated attributes of "learned helplessness" within women. Through the repeated experience of uncontrollable effects, many women come to believe that they cannot modify their environment or personal situations and thus their persistence in problem solving is diminished (Jack, 1992), leading to low self esteem and low self confidence. One cannot teach self-confidence and self-esteem; one must provide the conditions in which these can develop. Women must participate in problem definition, the identification of concrete solutions to problems, the implementation of these solutions, and the assessment of the efforts undertaken. As Hall (1992) notes, economic subordination must be neutralized for women to be empowered.

- The economic component of empowerment requires that women be able to engage in a productive activity that will allow them some degree of financial autonomy. of empowerment entails the ability to analyze the surrounding environment in political and social terms; it also means the ability to organize and mobilize for social change. In consequence, an empowerment process must involve Individual awareness, and collective action is fundamental to the aim of attaining social transformation.

Thus the above discussion leads to following conclusions about nature of empowerment:

\section{- The Process-oriented Nature of Empowerment}

Empowerment denotes a process of acquiring, providing, bestowing the resources and the means or enabling the access to and control over such means and resources. Instead, empowerment is a dynamic and on-going process which can only be located on a continuum (Shetty, 1992). Empowerment is a moving state; it is a continuum that varies in degrees of power. It is relative, one can move from an extreme state of absolute lack of power to the other extreme of having absolute power. The extreme ends of the continuum are of course "idealised" states.

\section{- $\quad$ The Holistic Nature of Empowerment}

Empowerment is an all encompassing term in which a whole range of economic, social and political activities, including group organisation, agriculture and income generation projects, education, integrated health care and so on, would work synergistically towards the common goal of empowering the poor (Bhasin, 1985).

- Empowerment Deals with Strategic rather than Practical Gender Interests It is important to differentiate between terms 'the practical gender interests' and 'the strategic gender interests'. Former are short term and linked to immediate needs arising from women's current responsibilities vis-a-vis the livelihood of their families and children, while the latter address bigger issues such as sexual division of labour within the home, the removal of institutionalised forms of gender discrimination, the establishment of political equality, freedom of choice over child-bearing, and the adoption of adequate measures against male violence and control over women. 


\section{- $\quad$ Context-specific Nature of Empowerment}

According to Shetty (1992), empowerment can be defined only within the local social, cultural, economic, political, and historical context.

\section{REFERENCES}

1. Batliwala, S. (1993): Empowerment of women in south Asia : Concepts and Practices: New Delhi : FAO - FFNC/AD.

2. Battiwala, S. (1994) : The meaning of women's empowerment : New concepts from action : In Sen, G. Germain, A. \& Chen, L.C. (eds) : population policies Reconsidered: Health, Empowerment and Rights : P.P. - 127 - 138.

3. Bhasin, K. (1985) : Women's education in development from welfare to empowerment convergence : 21 (4) : 5-17

4. Freire,P (1992) : Pedagogy of the oppressed : Middle Sex: Penguin Books.

5. Friedmann, J. (1992) : Empowerment : the politics of alternative development : oxford : Blackwell.

6. Jejeebhoy, S.J. (2000): women's autonomy in rural India: It's dimensions, determinants and the influence of context : In Harriet P. \& Sen, G: Women's empowerment and Demographic processess : Moving beyond caiso : New York : oxford university press.

7. Kabeer, N. (1998) : Money Can't Buy me love? Re-evaluating Gender, Credit and Empowerment in Rural Bangladesh : IDS discussion Paper : 363.

8. Kabeer, N. (1999 a) : Resources, agency, achievements : Reflections on the measurement of women's empowerment : Development and change : $30: 435$ - 464.

9. Kabeer, N. (1999 b) : From Feminist insight to an analytical framework : In N. Kabeer \& R. Subrahamanian (Eds): Institutions relations and outcomes: frame work and case studies for gener aware planning : New delhi : Kali for women : p.p. 3 - 48.

10. Kabeer, N. (2001) : Reflections on the Measurement of women's empowerment : In N. Kabeer (ed) : Discussing women's empowerment : theory and practice : stockhold Sida : pp $20-27$

11. Kabeer, N. (2001): Resources, Agency. Achievements : Reflection on the measurement of women empowerment : Side study no.3.

12. Rowlands, J. (1998): A word of times, but what does it mean? Empowerment in the discourse and practice of development : In Afshar, H. (ed) : Women and empowerment : Illustrations from the third world : New York : St. Martin Pren.

13. Rowlands, J.O. (1995): Empowerment examined : Development in Practice : 5(2) : 101 107 : p.p $101-107$

14. Shetty, S. (1992): Development projects in Assessing. empowering : new Delhi society for participatory Research in Asia : Paper series : 3.

How to cite this article: T Tandon (2016), Women Empowerment: Perspectives and Views, International Journal of Indian Psychology, Volume 3, Issue 3, No. 8, DIP: 18.01.134/20160303, ISBN: 978-1-365-12176-0 